\title{
Reviews
}

\section{Use of Hydrophylic Polymers in Horticulture}

\author{
M.D. Orzolek
}

Additional index words. fruits, vegetables, greenhouse, turf, application equipment

Summary. Hydrophylic polymers are synthetic, water-absorbing monomers of high molecular weight. They have been used as absorbents in the diaper industry for the past 30 years. Polymers differ from each other in the specific monomer building block, amount of water absorbed per gram of material, particle size and distribution, response to salinity, and cost. While there are only four different monomers used in the production of polymers, there are several dozen polymers available commercially under different trade names. Benefits derived from polymer application to soil or artificial medium include: increase in water-holding capacity, increase in pore size/number, increase in soil nutrient reserves, and reduction in soil compaction. Initial use of polymers was reported in greenhouse production in the late 1970 s, but is now used in the production of fruits, vegetables, and turf. Development of application equipment has the potential to expand the use of polymers to large commercial growers.

Department of Horticulture, The Pennsylvania State University, University Park, PA 16802.

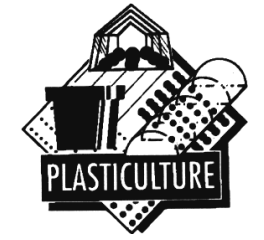

\section{General description}

Polymers are generally high-molecular-weight materials that can be synthesized from a variety of monomers. The resulting materials can be either hydrophylic or hydrophobic (Tess and Poehlein, 1985) Ideal with only the hydrophylic-type polymers. The chemical composition of these hydrophylic polymers includes: crosslinked acrylamide : sodium polyacrylates; swellable starch; crosslinked acrylamide : potassium polyacrylates; starch : acrylate copolymers; and acrylonitrile. Crosslinking in polymers appears to contribute to the increased storage of plant-available water in addition to acting as a physical barrier to the outflow of water from the gel (Johnson and Veltkamp, 1985). Such polymer types differ in the total amount of water absorbed per gram of material, particle size and distribution, response to salinity, and cost.

Polymers can absorb extremely high rates of distilled water (as much as 1000 times their weight), but, in field applications, hydration seldom exceeds 400 to 500 times their weight $(\mathrm{g} / \mathrm{g})$ due to the level of salinity in most water sources. As the concentration of ions increases in water, the amount of hydration by the polymer decreases (Evans et al., 1990). Particle size will vary from $5 \mu \mathrm{m}$ to $2 \mathrm{~mm}$ within a specific polymer and among polymer types.

Most polymers targeted for the horticultural industry are manufactured to meet the following criteria: increase a soil's water-holding capacity, increase pore size/number in soil, increase transplant survival rates, increase germination rates, and decrease or mitigate the effect of soil compaction on plant growth. In addition, several manufacturers have substituted potassium for sodium (commonly found in disposable baby diapers) in their products because of reduced toxicity to the plant. There have been very few, if any, long-term studies conducted to measure the breakdown rate of polymers under field conditions. Several manufacturers suggest that polymers will produce a significant benefit (water retention) for 5 years. Controlled degradation studies by me on several polymers indicated that polymers will lose $10 \%$ to $15 \%$ of their activity each year. The avenues ofpolymer degradation appear to be from microorganisms (Table 1), modification of physical structure over time, and chemical decomposition (Johnson, 1985).

\section{Uses in horticulture}

Greenhouse. Because the initial use of polymers was projected to increase the water-holding capacity of soil/soilless mixes used in the production of floral and nursery crops in the greenhouse, many of the early recommendations were developed for greenhouse crops (Bearce and McCollum, 1977; Foster and Keever, 1990; Gehring and Lewis III, 1980; Letey et al., 1992; Wang, 1989). Growerswere searching for methods that would increase the number of days between watering crops as well as reduce the total amount of water needed to grow their crops to maturity. Crop response to the addition of polymers in soil/ soilless media appeared to be greatest when incorporated in sands or media with low organic matter (Table 2). In addition, individual plant sensitivity to water stress affected response of the crop to polymer-modified soil. The rates of polymer application recommended by manufacturers range from 1 to $5 \mathrm{lb} / \mathrm{yd}^{3}$ of media.

One unusual use of a polymermodified soil was found for rooted cuttings. Banko (1984) reported an improvement in rooted cuttings of 
Table 1. Cumulative weight loss (\%) due to polymer decomposition by microbial activity (Jobnson, 1985).

\begin{tabular}{lcrrrrr}
\hline & \multicolumn{7}{c}{ Time (weeks) } \\
\cline { 2 - 7 } Polymer type & $\mathbf{1}$ & $\mathbf{2}$ & \multicolumn{1}{c}{$\mathbf{3}$} & \multicolumn{1}{c}{$\mathbf{4}$} & \multicolumn{1}{c}{$\mathbf{5}$} \\
\hline Starch polyacrylonitrile & 1.9 & 6.7 & 13.6 & 16.1 & 18.7 & 19.7 \\
Urea-formaldehyde & 1.4 & 2.7 & 3.9 & 5.6 & 7.3 & 9.5 \\
Vinyl alcohol acrylic acid & 0.0 & 1.4 & 2.4 & 2.8 & 3.5 & 4.9 \\
Polyacrylamide & 0.0 & 0.0 & 0.0 & 1.5 & 1.5 & 2.8 \\
\hline Least significant difference at $\mathrm{P}<0.05=3.9$ & & & & &
\end{tabular}

Least significant difference at $\mathrm{P}<0.05=3.9$.

Table 2. Growth response of mums in various soil mixes with and without a polymer (potassium propenoate-propenamile copolymer (Bearce and McCollum, 1977). ${ }^{z}$

\begin{tabular}{lcccc}
\hline Medium & Plant ht $(\mathrm{cm})$ & Flowers/pot & $\begin{array}{c}\text { Largest bloom } \\
\text { diam }(\mathrm{cm})\end{array}$ & $\begin{array}{c}\text { Plant dry } \\
\text { wt }(\mathrm{g})^{\mathrm{y}}\end{array}$ \\
\hline Peat-lite mix & $31.19 \mathrm{a}$ & $12.19 \mathrm{a}$ & $8.79 \mathrm{a}$ & $28.7 \mathrm{a}$ \\
Peat-lite with polymer & $35.22 \mathrm{~b}$ & $14.00 \mathrm{~b}$ & $10.11 \mathrm{~b}$ & $35.9 \mathrm{~b}$ \\
Bark mix & $30.30 \mathrm{a}$ & $13.90 \mathrm{ab}$ & $7.62 \mathrm{c}$ & $25.4 \mathrm{a}$ \\
Bark with polymer & $29.41 \mathrm{a}$ & $15.20 \mathrm{c}$ & $9.63 \mathrm{~b}$ & $28.0 \mathrm{a}$ \\
\hline
\end{tabular}

${ }^{z}$ Values within each column with the same sub-letter are not significantly different by means of Duncan's multiple range test at the $5 \%$ level.

${ }^{y}$ Five plants per pot.

holly and azalea from polymer incorporation into the rooting media. The larger roots of both the holly and azalea cuttings were attributed to a more uniform distribution ofmoisture through the rooting medium.

One potential application of polymers in greenhouse production is the use of polymer modules as a substrate for tomato production developed in England (American Greenhouse Vegetable Grower News, 1989). Each black/white polyethylene module contains two sheets of paper with polymer particles sandwiched between them. When lily hydrated, the substrate is $<10 \mathrm{~cm}$ deep. In comparison to tomato growth in rockwool, there was no difference in yield with the polymer substrate. However, the advantage of using polymers is the ease of disposal compared to other soilless substrates.

Vegetables. Use of polymers in the production of fruits andvegetables was accelerated greatly by the nationwide drought in 1991. Evaluation of polymers in various sizes of field trials was widespread in California, Arizona, and New Mexico. In 1991-92, a total of 2000 acres of various crops were treated with polymer in California alone (C.B. Wilde, personal communication). However, the increase in waterholding capacity of soils with the addition of polymers is dependent on soil type and level of organic matter found in the soil. Objectives of the applications were to reduce water application by $30 \%$ to $50 \%$ and to reduce fertilizer applications. Preliminary results appear to confirm the objectives of the field application of polymers in California. A reduction in time to crop maturity, yield increase of $30 \%$, and potentially higher soluble solids in the fruit were reported with an application of $15 \mathrm{lb}$ of polyacrylamide to processing tomatoes grown in California (Pryor, 1988). There also has been some indication that polymers enhance root development, resulting in improved plant growth (Figs. 1 and 2). Trials on a much smaller scale also were conducted by growers in Texas and Florida. The crop responses observed have been the elimination of plant growth cessation due to drought stress, increased nutrient uptake (Table 3 ), and increased crop yields. Initial questions that seemed to arise with the

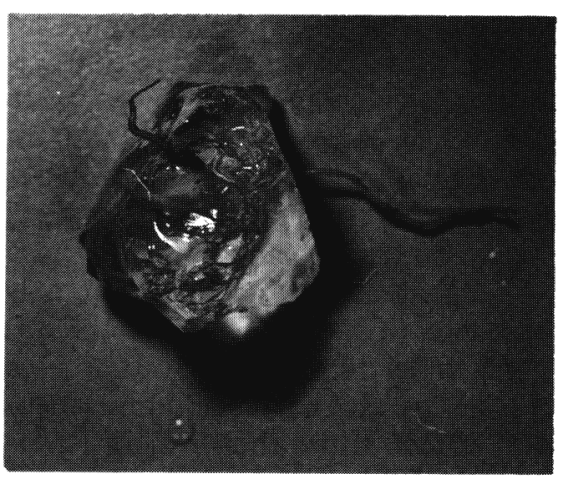

Fig. 1. Three-week-old tomato root growing through polyacrylamide crystal. (Photograph by Thomas Hopen, MVA Inc., Laurenceville, Ga. and Western Polyacrylamide Inc., Castle Rock, Colo.) use of polymers in the field for fruit and vegetable production were related to the rate, method, and type of application.

Recommendations based on academic and industrial research indicate that both broadcast and banded inthe-row applications of dry polymers produce a significant reduction in moisture stress to the crop and higher yields compared to crops produced without the application of polymers. The big difference between the two methods of application is the cost and total amount of polymer required. Advocates of broadcasting the polymer recommend applications between 150 and $800 \mathrm{lb} / \mathrm{acre}$ with incorporation to a depth of 6 to 8 inches. Banding the polymer in the furrow at transplanting required as little as $15 \mathrm{lb} /$ acre, with maximum application at 40 lb/acre $\left(46 \mathrm{~kg} \cdot \mathrm{ha}^{-1}\right)$. Initial research with banding the polymer in the furrow also indicated that total nutrient requirements for a specific crop could be reduced, because the polymer increased the reserve pool of nutrients in the soil and increased uptake efficiency in the plant (Orzolek, 1991).

No response in muskmelon, tomato, or bell pepper was observed when polymer was broadcast prior to laying polyethylene plastic mulch in Florida, Texas, and South Carolina (D. Wofford, Jr., personal communication). Rates applied were 15 to 40 lb/acre on different soil types.

Fruit and orchard crops. Individuals working with polymers in orchard application have applied polymers as a hydrated material successfully. They have reported lower tree mortality in newly established orchards and sustained active growth in established orchards under stress conditions. Because of the interest in injecting hydrated polymers in orchards, several injection machines have been designed in the western United States. In addition to applying polymers in the hydrated state, the application equipment has been designed to apply dry polymer at four or more different sites located around the drip line of trees. Initial reports from developers of equipment indicated good results with the equipment and with placement of the polymer in the drip-line area. The optimum polymer rate has been calculated to be $8 \mathrm{oz}$ of polymer in 80 gal of water per tree in orchards (C.B. Wilde, personal communica- 


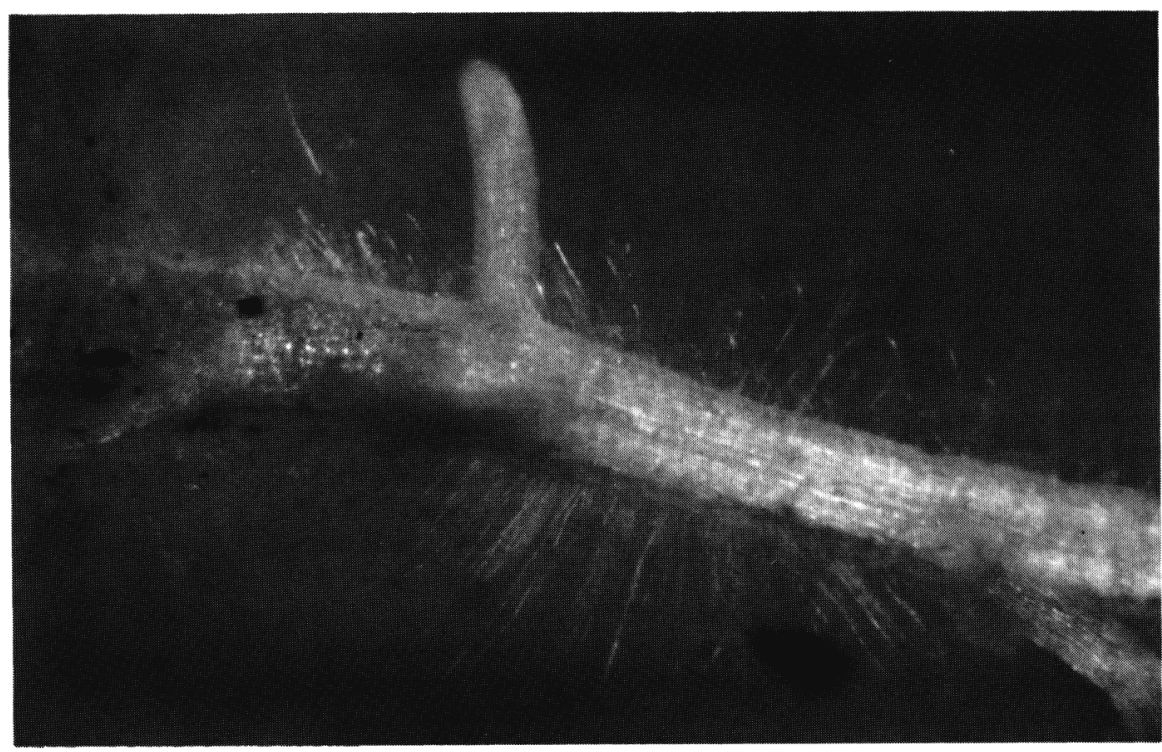

Fig. 2. Growth of 3-week-old tomato root in polyacrylamide crystal with enbanced root hair development. (Photograph by Thomas Hopen, MVA Inc., Laurenceville, Ga., and Western Polyacrylamide Inc., Castle Rock, Colo.)

tion). However, the rate of polymer application at each location should be determined by tree size, tree species, location, soil type, and rainfall amounts and distribution patterns.

Turf. Because of the shallow root system of many turfgrass species (as compared to most other horticultural crops) and continual traffic that occurs on a daily basis, many researchers have reported significant response in growth and appearance of turf following polymer applications (Nus et al., 1991; Van Hoozer, 1991; Vlach, 1990). Of all the different plant species evaluated with polymer trials, turf seems to be especially sensitive to high rates of polymer (>3 1b/1000 $\mathrm{ft}^{2}$ for established turf and $>1601 \mathrm{~b} /$ acre broadcast for newly seeded turf) incorporated into the .soil (MacPhail et al., 1980). However, researchers in the western United States have reported success with injection of 4 to $5 \mathrm{lb}$ of polymer/ $1000 \mathrm{ft}^{2}$ and have incorporated up to

Table 3. Effects of polymers on fertilizer $N$ use in bentgrass (Vlach, 1990).

\begin{tabular}{lcc}
\hline Polymer type $^{\mathbf{z}}$ & $\begin{array}{c}\text { Avg. tissue } \\
\text { N (\%) }\end{array}$ & $\begin{array}{c}\text { N up- } \\
\text { take (mg) }\end{array}$ \\
\hline Polyacrylamide A & 4.71 & $\mathbf{6 4 . 7}$ \\
Polyacrylamide B & 4.14 & $\mathbf{5 9 . 3}$ \\
Cross-linked starch a & 4.64 & $\mathbf{5 9 . 9}$ \\
Polyacrylamide C & 4.46 & $\mathbf{3 5 . 0}$ \\
Cross-linked starch b & 4.84 & $\mathbf{5 9 . 1}$ \\
No polymer & 4.23 & $\mathbf{3 2 . 4}$
\end{tabular}

$\overline{{ }^{z} \text { Lettersafter polymer type indicate different trade }}$ names of the polymer.
$30 \mathrm{lb}$ of polymer/1000ft in extremely sandy soils (D. Wofford, Jr., personal communication). Trials have been established in golf courses, soccer fields, cemeteries, and country clubs in both new plantings and established turf (Baker, 1991). Polymer incorporated into soccer fields has resulted in increased water retention, reduction in hardness due to dry weather, maintaining ground cover health after games, and a potential for reducing sports injuries. In new plantings, polymers can be applied (broadcast and incorporated) as dry material at the rate of 2 to $7 \mathrm{lb} / 1000 \mathrm{ft}^{2}$. In established turf, a uniform application of dry polymers can be difficult when knifed in at 9-inch spacings. However, it appears that injection of hydrated polymers in established turf is more successful and efficient than dry polymer application. Several individuals or companies have developed injectors for the application of hydrated polymers into turf.

Application equipment. There are several companies that recently have started to market polymer injection equipment nationally. Gene Seifert (Condor Industries Inc., Ogden, Utah) developed the Aqua-Life Tree Injector, which will inject either dry or hydrated polymers. The unit operates through an air compressor that fractures the soil near the tree stem prior to the polymer's being dispensed through the injector into the soil. The injector has been tested in orchards, street tree plantings, parks, and roadsides for establishment of trees and shrubs. Injection Aeration Systems Inc. (IAS) (Cerritos, Calif.) will be marketing three different polymer injectors: for orchard and vineyards, turf, and landscaping and home yards. All of these injectors from IAS are designed to inject the dry polymer using highpressure water injection (3000 psi) and a Venturi chamber. The Venturi chamber creates a vacuum that sucks the dry polymer from the polymer hopper into the stream of water. The injectors can place the polymer from 4 to 20 inches $(10$ to $50 \mathrm{~cm}$ ) beneath the soil surface, depending on individual crop application. Both polymer injectors also will aerate the soil and inject the polymer. The aeration of the soil can be as beneficial to the plant/crop as the polymer application itself.

\section{Conclusion}

The use of hydrophylic polymers for horticultural applications is in its infancy in the United States and other horticulturally productive countries of the world. As additional polymer research is conducted on methods of application, rates of application, interaction with nutrients, insecticides, fungicides, herbicides, and growth regulators, new uses for polymers will be uncovered by the scientific and business community. Potential benefits for the use of polymers in horticultural production include conservation of water, increased efficiency in water use by plants, more-efficient and uniform crop establishment, conservation of nutrients, increased crop growth, and increased crop yields.

\section{Literature Cited}

American Greenhouse Vegetable Growers News. 1989. Tomatoes in bags of jelly. Amer. Greenhouse Veg. Growers News May (5):5-6.

Baker, S.W. 1991. The effect of a polyacrylamide co-polymer on the performance on a Lolium perenne L. turf grown on a sand rootzone. J. Sports Turf Res. Inst. 67:6682 .

Banko, T.J. 1984. Medium amendment plus watering system may improve rooting. Amer. Nurseryman May (5):51-53.

Bearce, B.C. and R.W. McCollum. 1977. A comparison of peat-lite and noncomposted hardwood-bark mixes for use in pot and bedding-plant production and the effects of a new hydrogel soil amendment on their 
performance. Flor. Rev. 10:21-24.

Evans, R.Y, I. Sisto, and D.C. Bowman. 1990. The effectiveness of hydrogels in container plant production is reduced by fertilizer salts. Foliage Dig. 3:3-5.

Foster, W.J. and G. J. Keever. 1990. Water absorption of hydrophylic polymers (hydrogels) reduced by media amendments. J. Environ. Hort. 8(3):113-114.

Gegring, J.M. and A.J. Lewis III. 1980. Effect of hydrogel on wilting and moisture stress of bedding plants. J. Amer. Soc. Hort. Sci. 105(4):511-513.

Johnson, M.S. 1985. Degradation of waterabsorbing polymers used as soil ameliorants. Arab. Gulf. J. Sci. Res. 3(2):745-750.

Johnson, M.S. and C.J. Veltkamp. 1985. Structure and functioning ofwater-storing agricultural polyacrylamides. J. Sci. Food Agr. 36:789-793.

Letey, J., P.R. Clark, and C. Amrhein. 1992. Water-sorbing polymers do not conserve water. Calif. Agr. 46(3):9-10.

MacPhail, J.M., J.L. Emens, P.M. Harney, and M.J. Tsujita. 1980. Effect of Viterra 2 hydrogel on germination, seedling growth and sod establishment of Kentucky bluegrass. Can. J. Plant Sci. 60:665-668.

Nus, J., M. Boaz, and D. Wofford, Jr. 1991. Water-absorbing polymers show promise in turf. Golf \& Sports Turf. June. p.4.

Orzolek, M.D. 1991. Reduction of nitrogen requirement for vegetable production with polymers. Proc. 23rd Natl. Agr. Plastics Congr. p. 204-210.

Pvor, A. 1988. Pretty poly. California Farmer. Oct. (10):12.

Tess, R. W. and G.W. Poehlein. 1985. Applied polymer science. ACS Symp. Ser. 285. Amer. Chem. Soc., Washington, D.C.

Van Hoozer, G. 1991. Pain relief: Polymers save water and reduce injuries. Turf South Apr. (4):36-39.

Vlack, T.R. 1990. Creeping bentgrass responses to water absorbing polymers in simulated golf greens. The Grass RootsWisc. GCSA Publ. July/Aug. p. 3.

Want, Y.T1989. Medium and hydrogel affect production and wilting of tropical ornamental plants. HortScience 24(6): 941-944.

\section{Resources}

Condor Industries Inc., P.O. Box 3290, Ogden, UT 84409; phone 801/479. 8753.

Injection Aeration Systems Inc. (IAS), P.O. Box 4763, Cerritos, CA 90703; phone 310/823-1999. 